\begin{tabular}{|c|c|c|}
\hline & PORT-SAID ENGINEERING RESEARCH JOURNAL \\
\hline
\end{tabular}

\title{
Design Methodology of a New Surface Flow Constructed Wetland System, Case Study: East South EL-Kantara Region North Sinai, Egypt
}

Mohamed E. Gabr ${ }^{1}$

\begin{abstract}
In this paper, a model was developed based on simple equations to design a surface flow constructed wetland system (SFCWL). The hydraulics of the system and the pollutant removal were based on first-order plug flow assumptions (k$\mathrm{C}^{*}$ model) to remove biological oxygen demand (BOD), fecal coliforms (FC), total suspended solids (TSS), total nitrogen (TN) and total phosphorus (TP). In addition, the (SFCWL) hydrology was considered. The model was applied to design a new (SFCWL) of vegetated cells (reed) followed by a storage pond system to treat $6000 \mathrm{~m}^{3} /$ day of the degraded agricultural drainage water in the East South EL-Kantara region, North Sinai, Egypt. The model input data were summer air temperature $27{ }^{\circ} \mathrm{C}$, winter air temperature $15^{\circ} \mathrm{C}$ and influent concentrations for (BOD) $120 \mathrm{mg} / \mathrm{L}$, (FC) 100000 CFU/100 mL, (TSS) $155 \mathrm{mg} / \mathrm{L}$, (TN) $20 \mathrm{mg} / \mathrm{L}$ and (TP) $5 \mathrm{mg} / \mathrm{L}$. The model output showed 3.54 days retention time and the total area of the system, including storage pond was 25.7 hectares. The expected overall pollutant removal efficiencies for (BOD), (FC), (TSS), (TN) and (TP) were 83.3\%, 99.5\%, 88.6\%, 66\% and 50\% respectively. The proposed (SFCWL) system as a promising low-cost treatment alternative can change polluted agriculture drainage water to an unconventional water source that will be utilized for irrigation and environment-friendly.
\end{abstract}

Keywords: Wastewater treatment, free surface constructed wetland, agriculture drainage water, reed plant, Egypt

\section{INTRODUCTION}

Pollution of water sources by discharging of inadequate treating wastewater as a result of increasing populations, economic and industrial development and agricultural activities is a rising problem around the world [1] [2] [3]. Constructed wetlands (CWs) treating system have been spread around the world especially in small to medium societies where it provides high removal pollutant efficiencies, simple and reliable operation and low operation/maintenance cost [4] [5] [6]. (CWs) projects have been implemented in a number of countries to address different types of waste [7] [8] [9]. Various design procedures for $(\mathrm{CWs})$ projects have been presented in literature [10 to 13]. As a general conclusion, the constructed wetland treatment systems prove its ability to remove pollutants in a ratio more than $90 \%$ of total suspended solids (TSS), biological oxygen demand (BOD), chemical oxygen demand (COD) and Fecal coliforms (FC) from the wastewater. In addition, the removal of total phosphorus (TP) and total Nitrogen (TN) remains, however closer to $50 \%$ in most cases [14 to 17]. In Egypt, the free water surface constructed wetland project in Lake EL-Manzala to treat 25,000 m3/day of the wastewater of Bahr El Baqar drain has been evidenced to environmentally remarkable and economically feasible [18] [19]. Water hyacinth, reed and duckweed are the common plants used in the project to remove wastewater pollutants [20]. The study area (Tina Plain and East South EL-Kantars regions are agro-ecological regions (31500 hectares) lie in the North Sinai Peninsula.

1 Civil Engineering Department, High Institute for Engineering and Technology, New Damietta, Ministry of HighEducation,Egypt; m_egabr@yahoo.com.
It is a part of the North Sinai Development Project (NSDP) to reclaim and cultivate 52500 hectares. The study area has semi-arid climate conditions. The major cultivated crops are Wheat, Barely, Alfalfa, Green Beans, Tomato, Sugar beet, Cotton and Maize. More than 25000 inhabitants whose daily sewage water are about $2500 \mathrm{~m}^{3}$ is dumped into the drainage network polluting the agriculture drainage water and soil, since the sewerage system in the area has not been constructed. In this study, a design methodology for a surface flow constructed wetland (SFCWL) to treat the degraded agriculture drainage water in East South EL-Kantara region, North Sinai, Egypt was developed. The system model has the capability to remove (BOD), (TSS), (FC), (TN) and (TP). The Wetland hydrologic study was carried out based on the climatic data for the period from 1985 to 2015 from Ismailia weather station, Egypt (the nearest weather station for the study area) that obtained from the CLIMWAT 2.0 tool attached to the CROPWAT 8.0 software developed by FAO (2019) [21]. Treatment performance was based on the classic first-order kinetic rate constants for polluted wastewater $\left(\mathrm{k}-\mathrm{C}^{*}\right.$ model) in computing pollutant removal efficiencies in the in (SFCWL) system developed by USEPA (1999) [3] and Reed et al. 1995 [11]. The model methodology was validated by comparing the computed wetland area with the existing surface flow constructed wetland system database in the U.S [12]. To promote sustainable management of natural resources, the model was applied to design (SFCWL) of vegetated surface wetland cells (reed) followed by a storage pond system to treat 6000 $\mathrm{m}^{3} /$ day of the degraded agricultural drainage wastewater in the study area. 


\section{MATERIALS AND METHODS 2.1. Site Description}

The study area lies in North Sinai, Egypt. It is a part of the North Sinai Development Project (NSDP), Sector of Water Resources and Infrastructure in the North of Sinai is responsible for the operation and maintaining of the irrigation and drainage networks (Fig. 1) [22].

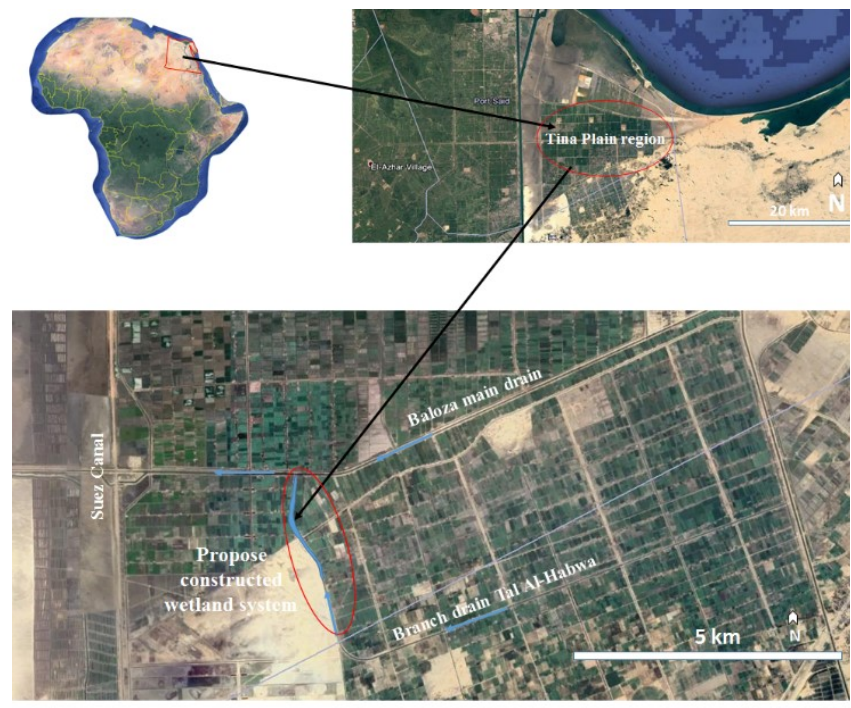

Fig. 1: Location of the study area

EL-Sheikh Gaber Canal is the main freshwater source for (NSDP). Tina plain area is characterized by clay soil ranging from light to heavy clay. As it is originally part of the Nile Delta, which is flat or light inclined, rising at an average of about $5 \mathrm{~m}$ above mean sea level [23]. ElFarama main drain is located in the Northern part of Tina plain. It collects the drainage water from branch-drains numbers 1, 3, 5 and 7 with total discharge of $6 \mathrm{~m}^{3} / \mathrm{s}$. ElFarama drainage water is dumping into Suez Canal through El-Farama pump station at Km 21.4 south Port Said (Fig. 2). Baloza main drain is located in the south part of Tina plain. It collects the drainage water from the branch-drains numbers 2, 4, 6, 8 and 10 . In addition, Tel Al-Hair and Tal Habwah drains. The length of Baloza main drain is about 17.6 kilometres and Baloza pump station at $\mathrm{Km} 34$ south of Port Said governate which pumping the drainage water $\left(15.6 \mathrm{~m}^{3} / \mathrm{s}\right)$ into Suez Canal. Branch canals numbers 1, 3, 5 and 7 were assigned to ElFarama drainage area, and Branch canals numbers of 2, 4, 6 and 8 are assigned to the Baloza drainage area (Fig. 2) [22]. The climate in this area is characterized by semi-arid conditions hot and dry in summer and cold in winter [23]. Climatic data during 1985 to 2015 in Ismailia weather station (nearest station for East South EL-Kantara Region) were obtained from the CLIMWAT 2.0 model attached to the CROPWAT 8.0 software [21] and the FAO Penman-Monteith equation was utilized to calculation of the reference evapotranspiration (ETo).

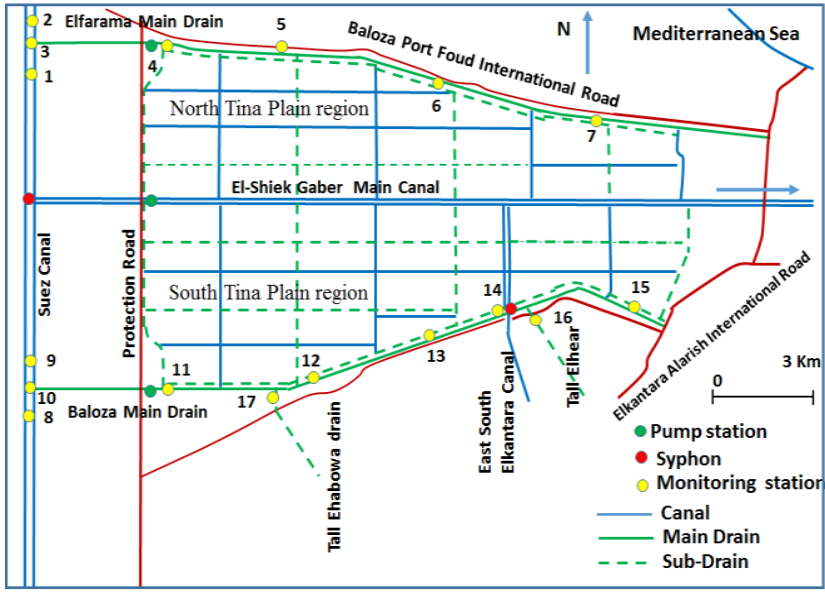

Fig. 2: water quality monitoring stations distributed in the drainage networks in Tina Plain region.

Water quality monitoring stations are distributed in the drainage networks in the Tina Plain region. Table 1 summarizes Ismailia Station monthly normal climate data (minimum temperature in $\left({ }^{\circ} \mathrm{C}\right)$, maximum temperature $\left({ }^{\circ} \mathrm{C}\right)$, wind speed $(\mathrm{km} /$ day), relative humidity $(\%)$, sun radiation energy $\left(\mathrm{MJ} / \mathrm{m}^{2} /\right.$ day $)$, sunshine hours (h), reference evapotranspiration (ETo) ( $\mathrm{mm} /$ day), rains $(\mathrm{mm})$, and the net precipitation $(\mathrm{mm})$ (precipitation rate subtract evaporation rate). The proposed new constructed wetland site lies at the upstream bank of branch drain Tal Al-Habwa East, South EL-Kantara region (Fig. 3). The selected wetland site is adjacent to an existing road system to reduce the construction cost; moreover, evaluation and maintenance are two major components in constructing wetland operation.

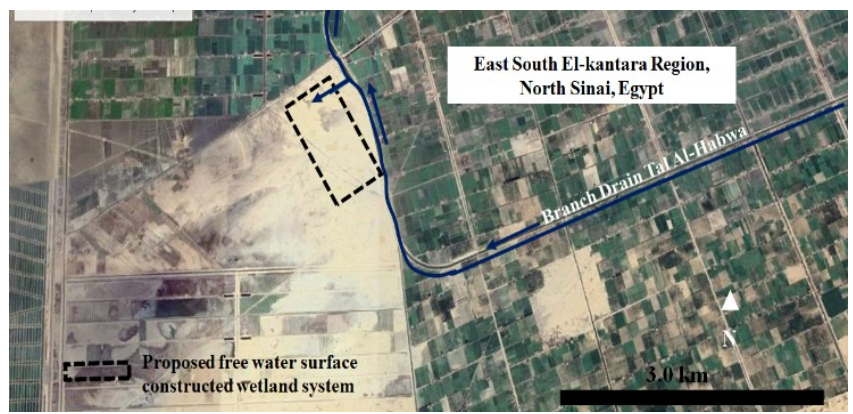

Fig. 3: Proposed surface flow constructed wetland site

\subsection{Drainage Water Sampling Data}

Drainage water sampling data were collected from 15 monitoring points distributed in the study drains, therefore the monitoring points number 1,2 and 3 lie in the Suez Canal and the points 4, 5, 6 and 7 lie in El-Farama main drain. Then the points 8, 9 and 10 lie in Suez Canal and points 11, 12, 13, 14 lie in Baloza main drain. Point 15 lies in the outlet of the Tal Habwah branch drain (Fig. 2). Water samples were collected every 3 months (each season) using water sampler according to the principles referenced in [24] between April 2009 to June 2010 [25]. 
Table. 1 Climatic data rainfall and reference evapotranspiration (ETo) of Ismailia Station [21].

Country: Egypt (location 7) Altitude: $13.0 \mathrm{~m}$

\section{Station: Ismailia} Latitude: $30.60 \mathrm{~N}^{\mathrm{o}}$

Longitude: $32.25 \mathrm{E}^{0}$

\begin{tabular}{|l|c|c|c|c|c|c|c|c|c|}
\hline \multicolumn{1}{|c|}{ Month } & $\begin{array}{c}\text { Min. } \\
\text { Temp. } \\
\left({ }^{\circ} \mathbf{C}\right)\end{array}$ & $\begin{array}{c}\text { Max. } \\
\text { Temp. } \\
\left({ }^{\circ} \mathbf{C}\right)\end{array}$ & $\begin{array}{c}\text { R. Hum. } \\
\mathbf{( \% )}\end{array}$ & $\begin{array}{c}\text { Wind } \\
\text { Speed } \\
(\mathbf{k m} / \mathbf{d a y})\end{array}$ & $\begin{array}{c}\text { Sun- } \\
\mathbf{s h i n e} \\
(\mathbf{h o u r})\end{array}$ & $\begin{array}{c}\text { Sun } \\
\text { Radiation } \\
\left(\mathbf{M J} / \mathbf{m}^{2} / \mathbf{d a y}\right)\end{array}$ & $\begin{array}{c}\text { ETo } \\
(\mathbf{m m} / \mathbf{d a y})\end{array}$ & $\begin{array}{c}\text { Rainfall } \\
(\mathbf{m m} / \\
\mathbf{m o n t h})\end{array}$ & $\begin{array}{c}\text { Net } \\
\text { Rainfall } \\
(\mathbf{m m} / \mathbf{d a y})\end{array}$ \\
\hline January & 7.6 & 19.2 & 53 & 207 & 6.2 & 11.6 & 2.65 & 7.0 & -2.42 \\
\hline February & 8.3 & 20.9 & 50 & 251 & 6.9 & 14.4 & 3.48 & 6.0 & -3.28 \\
\hline March & 10.3 & 23.3 & 45 & 285 & 7.6 & 17.9 & 4.65 & 7.0 & -4.42 \\
\hline April & 14.1 & 28.6 & 38 & 277 & 8.5 & 21.4 & 6.26 & 2.0 & -6.19 \\
\hline May & 16.4 & 31.8 & 37 & 259 & 9.4 & 23.9 & 7.09 & 2.0 & -7.02 \\
\hline June & 19.5 & 34.8 & 39 & 277 & 10.7 & 26.1 & 8.03 & 0.0 & -8.03 \\
\hline July & 21.3 & 35.7 & 40 & 242 & 10.4 & 25.5 & 7.75 & 0.0 & -7.75 \\
\hline August & 21.5 & 35.3 & 43 & 216 & 10.1 & 24.0 & 7.04 & 0.0 & -7.04 \\
\hline September & 19.7 & 33.1 & 48 & 199 & 9.4 & 21.1 & 5.82 & 0.0 & -5.82 \\
\hline October & 16.6 & 30.0 & 53 & 190 & 8.4 & 16.9 & 4.46 & 2.0 & -4.39 \\
\hline November & 12.7 & 25.4 & 59 & 138 & 7.3 & 13.1 & 2.82 & 6.0 & -2.62 \\
\hline December & 8.9 & 20.9 & 62 & 173 & 6.1 & 10.8 & 2.31 & 5.0 & -2.14 \\
\hline Average & 14.7 & 28.3 & 47 & 226 & 8.4 & 18.9 & 5.20 & 3.08 & -5.09 \\
\hline
\end{tabular}

Min. Temp., Minimum temperature; Max. Temp., Maximum temperature; and R. Hum., Relative Humidity.

-The negatives value means evaporation is higher than precipitation.

Table 2: Statistical measured seasonal water quality parameters for Tall EL-Habowa branch-drain [25].

\begin{tabular}{|c|c|c|c|c|c|c|c|c|}
\hline $\begin{array}{l}\text { Water parameter/ } \\
\text { Season }\end{array}$ & $\begin{array}{l}\text { (TDS) } \\
(\mathrm{mg} / \mathrm{L})\end{array}$ & (pH) & $\begin{array}{l}(\mathrm{TSS}) \\
(\mathrm{mg} / \mathrm{L})\end{array}$ & $\begin{array}{l}\text { (BOD) } \\
(\mathrm{mg} / \mathrm{L})\end{array}$ & $\begin{array}{c}\left(\mathrm{NO}_{3}\right) \\
(\mathrm{mg} / \mathrm{L})\end{array}$ & $\begin{array}{c}(\mathrm{Fe}) \\
(\mathrm{mg} / \mathrm{L})\end{array}$ & $\begin{array}{c}(\mathrm{Zn}) \\
(\mathrm{mg} / \mathrm{L})\end{array}$ & $\begin{array}{c}(\mathrm{FC}) \\
(\mathrm{CFU} / \mathbf{1 0 0} \mathrm{mL})\end{array}$ \\
\hline Spring & 7200 & 8.03 & 342 & 35 & 17.00 & 1.53 & 1.09 & 152 \\
\hline Summer & 7379 & 8.05 & 79 & 64 & 80.00 & 0.55 & 0.11 & 100 \\
\hline Autumn & 10277 & 7.6 & 155 & 70 & 6.56 & 3.24 & 1.46 & 755 \\
\hline Winter & 8166 & 7.99 & 42 & 80 & 10.17 & 1.93 & 1.86 & 1065 \\
\hline Average & 8256 & 7.92 & 155 & 62 & 28.46 & 1.83 & 1.13 & 518 \\
\hline Max. & 10277 & 8.05 & 342 & 80 & 80 & 3.24 & 1.86 & 1065 \\
\hline Min. & 7200 & 7.6 & 42 & 35 & 6.56 & 0.55 & 0.11 & 100 \\
\hline Standard deviation & 1222.38 & 0.18 & 115.66 & 16.74 & 30.01 & 0.97 & 0.65 & 407 \\
\hline $\begin{array}{l}\text { Egypt Decree } \\
(92 / 2013)[26]\end{array}$ & 2000 & $6-9$ & - & 6 & - & 0.5 & 0.01 & - \\
\hline
\end{tabular}

(TDS), Total dissolved solids; (TSS), total suspended solids; (BOD), Biological oxygen demand; $\left(\mathrm{NO}_{3}\right), \mathrm{Nitrate}$ (Fe),

Iron; (Zn), Zinc; and (FC), fecal coliform.

The water samples were sent to the Center Laboratory for Environmental Quality Monitoring, National Water Research Center, Cairo, Egypt. They were analysed for the water quality parameters total dissolved solids (TDS), $\mathrm{pH},(\mathrm{TSS}),(\mathrm{BOD})$, Nitrate $\left(\mathrm{NO}_{3}\right)$, Iron (Fe), Zinc ( $\left.\mathrm{Zn}\right)$ and fecal coliforms (FC). Table 2 summarizes the drainage water quality parameters for Tal Al-Habwa branch drain on Baloza Drain where, $\mathrm{pH}$ concentration ranges from 7.6 to 8.05 with an average $(7.9 \mp 0.18)$. (BOD) concentration ranges from 35 to $80 \mathrm{mg} / \mathrm{L}$ with an average $(62.25$ 干16.74) $\mathrm{mg} / \mathrm{L}$. (TSS) concentration ranges from 42 to 342 $\mathrm{mg} / \mathrm{L}$ with an average $(154.5 \mp 115.66) \mathrm{mg} / \mathrm{L} . \quad \mathrm{NO}_{3}$ concentration ranges from 6.56 to $80 \mathrm{mg} / \mathrm{L}$ with average (28.43干30.01) $\mathrm{mg} / \mathrm{L}$. Fe concentration ranges from 0.55 to $3.24 \mathrm{mg} / \mathrm{L}$ with an average $(1.81 \mp 0.97) \mathrm{mg} / \mathrm{L}$. Zn concentration ranges from 0.11 to $1.86 \mathrm{mg} / \mathrm{L}$ with an average $(1.16 \mp 0.65) \mathrm{mg} / \mathrm{L}$. (TC) concentration ranges from 100 to $1065 \mathrm{FCU} / 100 \mathrm{~mL}$ with an average
(518干407) FCU/100 mL. Additional details of this study about the site investigations and drainage water quality are provided in [25]. In addition, the permissible limits of pollutants according to Egyptian Decree 92/2013 [26] for the protection of the Nile River and its waterways from pollution are summarized in Table 2 .

\subsection{Wetland Hydrology}

The wetland hydrological balance is designed according to Kadlec and Wallace [17] as follows:

$$
\mathrm{Q}_{\mathrm{e}}=\mathrm{Q}_{\mathrm{i}}+(\mathrm{P}-\mathrm{ETo}-\mathrm{ETc}) \mathrm{A}
$$

Where: $Q_{e}$ is the effluent flow rate $\left(\mathrm{m}^{3} /\right.$ day), $Q_{i}$ is the untreated influent (inlet flow rate) $\left(\mathrm{m}^{3} /\right.$ day), $\mathrm{P}$ is the rainfall rate in ( $\mathrm{m} /$ day), (ETo) is the potential evaporation 
rate $(\mathrm{m} /$ day $),(\mathrm{ETc})$ is the evapotranspiration rate $(\mathrm{m} /$ day) and (A) is the water surface area of the wetland $\left(\mathrm{m}^{2}\right)$.

\subsection{Treatment Performance}

In this study, the first-order kinetic rate constants for polluted wastewater was applied to compute pollutant removal efficiencies in the (SFCWL) [3] [11]. The water temperature is assumed nearly equal to the mean ambient temperature according to the principle of Kadlec and Knight [12]. The Nitrogen and (BOD) removal rate is estimated according to [11] as follows:

$\frac{\mathrm{C}_{\mathrm{e}}}{\mathrm{C}_{\mathrm{i}}}=\mathrm{e}^{-\mathrm{K}_{\mathrm{T}} \mathrm{RT}}$

where: $\mathrm{C}_{\mathrm{e}}$ is the outlet concentration $(\mathrm{mg} / \mathrm{L})$ of $(\mathrm{BOD})$ and Nitrogen, $\mathrm{C}_{\mathrm{i}}$ is the inlet concentration of (BOD) and Nitrogen in $(\mathrm{mg} / \mathrm{L}), \mathrm{K}_{\mathrm{T}}$ is a reaction rate factor $\left(\mathrm{day}^{-1}\right)$ dependent on the water temperature $\mathrm{T}\left({ }^{\circ} \mathrm{C}\right)$. According to [11] for $(\mathrm{BOD}), \mathrm{K}_{\mathrm{T}}=0.678(1.06)^{\mathrm{T}-20}$, for Nitrogen Nitrification, $\mathrm{K}_{\mathrm{T}}=0.0389 \mathrm{~T}$ where $\left(0<\mathrm{T}<1{ }^{\circ} \mathrm{C}\right)$, $\mathrm{K}_{\mathrm{T}}=0.1367(1.15)^{\mathrm{T}-10}$ where $\left(1.0<\mathrm{T}<10 \quad{ }^{\circ} \mathrm{C}\right)$, $\mathrm{K}_{\mathrm{T}}=0.2187(1.048)^{\mathrm{T}-20}$ where, $(\mathrm{T}>10 \mathrm{oC})$, for Nitrogen Denirification $\mathrm{K}_{\mathrm{T}}=0.023 \mathrm{~T}$ where $(0<\mathrm{T}<1$ ${ }^{\circ} \mathrm{C}$ ) and $\mathrm{K}_{\mathrm{T}}=(1.15)^{\mathrm{T}-10}$ where $\left(\mathrm{T}>1{ }^{\circ} \mathrm{C}\right)$, and RT is the hydraulic residence time for the system in days. Fecal coliforms (FC) and total Phosphorus (TP) removal by Kadlec and Knight [12] principle is as follows:

$\frac{\mathrm{C}_{\mathrm{e}}}{\mathrm{C}_{\mathrm{i}}}=\mathrm{e}^{-\frac{\mathrm{K}_{1}}{\mathrm{RL}}}$

Where: $C_{e}$ is the pollutant outlet concentration (number of fecal coliforms $/ 100 \mathrm{~mL}$ ) or Phosphorus $(\mathrm{mg} / \mathrm{L}), \mathrm{C}_{\mathrm{i}}$ is the inlet influent concentration (number of fecal coliforms $/ 100 \mathrm{~mL}$ ) or total phosphorus $(\mathrm{mg} / \mathrm{l}), \mathrm{K}_{1}$ is a reaction rate parameter (m/day) [12], for ( $\mathrm{FC}), K_{1}=0.3$, and for (TP) $K_{1}=0.0273$ ), and RL is the hydraulic loading rate (m/day). The RL and RT parameters are defined as follows:

$\mathrm{RL}=\frac{\mathrm{Q}}{\mathrm{A}}$

$\mathrm{RT}=\frac{\mathrm{V}}{\mathrm{Q}}=\frac{\mathrm{Adn}}{\mathrm{RLA}}=\frac{\mathrm{dn}}{\mathrm{RL}}$

Where, $\mathrm{V}$ is the system volume $\left(\mathrm{m}^{3}\right), \mathrm{Q}$ is the constant design discharge rate $\left(\mathrm{m}^{3} /\right.$ day), A is the average surface area of the system $\left(\mathrm{m}^{2}\right), \mathrm{d}$ is the flow depth $(\mathrm{m})$ and $\mathrm{n}$ is the soil porosity given by [11]. Reed et al. (1995), based on operational experience of several constructed wetland systems in the United States reported that the organic loading in free water constructed wetland systems should not greater than $10 \mathrm{~g} / \mathrm{m}^{2} /$ day as a limit value, which can be expressed as follows:

$C_{i} \frac{Q}{A} \leq 10$

For new system the designed area is not known therefore the estimation of the organic loading needs a trial-anderror technique, to assure oxygen availability for nitrification in (SFCWL) and maximize ammonia removal efficiency [11]. Reed and Brown [27] advice of a minimum design RT of about 6 to 8 days. In addition, the removal of Phosphorus is in a range between 30 to $50 \%$ in the long term.

\subsection{Wetland Hydraulic Design}

The general equation for the hydraulic design of (SFCWL) recommended by Kadlec and Knight [12] is as follows:

$\mathrm{Q}=\mathrm{x} \mathrm{B} \mathrm{d} \mathrm{d}^{\mathrm{y}}$

Where $Q$ is the design flow rate $\left(\mathrm{m}^{3} /\right.$ day $), \mathrm{d}$ is the flow depth in (m) usually ranges from $0.1 \mathrm{~m}$ to $0.6 \mathrm{~m}$ [11], B is the wetland width $(\mathrm{m}), \mathrm{x}, \mathrm{y}$, and $\mathrm{z}$ are coefficients assumed to be of the following values $\mathrm{x}=10^{7} \mathrm{day}^{-1} \mathrm{~m}^{-1}$ for dense vegetation, $x=5 \times 10^{7}$ day $^{-1} \mathrm{~m}^{-1}$ for sparse vegetation, $\mathrm{y}=$ 3.0, and $\mathrm{z}=1.0$, and $\mathrm{S}$ is the water surface slope (dimensionless) estimated as follows:

$\mathrm{S}=\alpha \mathrm{d} / \mathrm{L}$

where $\mathrm{L}$ is the wetland length (m), and $\alpha$ is the fraction of the depth serving as head differential [11]. Economopoulou and Tsihrintzis [13] developed the following equation to estimate the free surface wetland water depth:

$\mathrm{d}=\left(\frac{\mathrm{L} Q \mathrm{Q}}{\mathrm{x} \alpha}\right)^{0.25}$

The suggested aspect ratio of the length to the width (L: B) should be greater than 2:1 to ensure plug flow conditions. Commonly used aspect ratios are between 2:1 and 5:1. 


\subsection{Nitrogen Removal Simplification}

Economopoulou and Tsihrintzis [13] suggested the following equation for the total nitrogen removal efficiency:

$\frac{C_{e}}{C_{i}}=e^{-K_{T N} R T}+e^{-K_{T D} R T}-e^{-K_{T N} t} e^{-K_{T D} R T}$

Where: $\mathrm{C}_{\mathrm{i}}$ is the total Kjeldahl nitrogen inlet concentration (assumed all converted to ammonia) $(\mathrm{mg} / \mathrm{L})$, and $\mathrm{C}_{\mathrm{e}}$ is the total nitrogen outlet concentration $(\mathrm{mg} / \mathrm{L}), \mathrm{K}_{\mathrm{TN}}$ and $\mathrm{K}_{\mathrm{TD}}$ are the reaction rate parameters for nitrification and denitrification $\left(\right.$ day $\left.^{-1}\right)$. To simplify the computation of the total nitrogen removal ratio in the new constructed wetland sizing problem, the curves of Fig. 4 provides a graphical solution to Equation (11), permitting for direct approximation of RT for total Nitrogen removal as a function of temperature $(\mathrm{T})$ and $\frac{\mathrm{C}_{\mathrm{e}}}{\mathrm{C}_{\mathrm{i}}}$.

\subsection{Estimation of the Organic Loading}

The water surface area (A) of the system is not known in advance in case of the design of a new free water surface constructed wetland system, thus if the (BOD) removal is required, the value of $\mathrm{KT}$ in Equation (1) should satisfy the following formula:

$K_{T} \leq-\frac{10 \ln \left(\frac{C_{e}}{C_{i}}\right)}{C_{i} d n}$

\section{8 (TSS) Removal}

TSS removal processes depend on the filtration and retention times, the removal equation developed by Reed et al. 1995 [11] in (SFCWL) as follows:

$\mathrm{C}_{\mathrm{e}}=\mathrm{C}_{\mathrm{i}}\{0.1139+0.00213(\mathrm{RL})\}$

where $\mathrm{C}_{\mathrm{e}}$ is the outlet TSS $(\mathrm{mg} / \mathrm{L}) ; \mathrm{C}_{\mathrm{i}}$ is the inlet (TSS) $(\mathrm{mg} / \mathrm{L})$. The wetland treatment performance $(\mathrm{CR})$ is given as follows,

$\mathrm{CR}=\frac{\mathrm{C}_{\mathrm{i}}-\mathrm{C}_{\mathrm{e}}}{\mathrm{C}_{\mathrm{i}}}$

\subsection{Design Methodology}

A flow chart diagram for the methodology used in the sizing a new free water surface constructed wetlands system is shown in Fig. 5.

\subsection{Methodology Validation with Existing Data}

Model validation was carried out by computing the area of some SFCWL in the U.S based on the available database in terms of temperature $\left.{ }^{\circ} \mathrm{C}\right)$, discharge $\left(\mathrm{m}^{3} /\right.$ day), influent (BOD) $(\mathrm{mg} / \mathrm{L})$, effluent (BOD), total influent nitrogen $(\mathrm{TN})(\mathrm{mg} / \mathrm{L})$, total effluent $(\mathrm{TN})$, total influent total phosphors (TP) $(\mathrm{mg} / \mathrm{L})$ and total effluent. The computed (SFCWL) area was matched with the existing real wetland area.
Table 3 summarizes the collected available data about five (SFCWL) in the USA in terms of temperature, discharge, and the inlet and outlet concentrations of (BOD), (TN), and (TP) [12]. The water temperature was considered equal to the mean air temperature. The following assumptions were made for some design parameters need in the model application and not available in the collected data: soil porosity $(n)=0.65, \alpha=0.1$ were assumed in estimating the system's surface area and use of Equation (9) with $\mathrm{x}=10^{7} \mathrm{day}^{-1} \mathrm{~m}^{-1}$ (dense vegetation). Length and width of the free water surface constructed wetland (L: B) ratio was taken equal to $2: 1$, and 5:1. The matching ratios for the area show an average reduction in the area of $17.3 \%$ for aspect ratios $\mathrm{L}: \mathrm{B}=2: 1$ and $29.2 \%$ for aspect ratios $\mathrm{L}: \mathrm{B}=5: 1$.

\section{RESULTS AND DISCUSSION}

\subsection{Drainage Water Quality}

The measured water quality parameters values (Table 2) were at the permissible limits of the Egyptian Decree 92/2013 [26] for the protection of the Nile River and its waterways from pollution except for the (TDS), (Fe), and $(\mathrm{Zn})$ concentration. Therefore, the drainage water needs treatment prior to discharge in the Suez Canal. The study area has a shortage in sanitary and potable water services and landowners started to build houses and livestock cattle on the drain, banks, it is expected to have pollution sources that will deteriorate the water drains.

Moreover, solid wastes, food and industrial wastes might be sharing the municipal wastewater sources. These pollution sources might be duplicated with population increasing rates. The growing agricultural activity in the region will also lead products, mills, rice paddies and the mobilization of agricultural products, which in turn use water in their industrial processes and thus produce quantities of water contaminated organic and chemical loads $[28,29]$.

\subsection{Design Steps of (SFCWL) System in Tal El- Habow.}

The irrigation served area of Tal EL-Habow drain is about 4200 hectares, the population intensity in its area is about 5000 capita in winter and 6000 capita in summer. Summer population is greater than winter population as some farmers come to the study region for employment [26]. For a unit wastewater flow of $0.15 \mathrm{~m}^{3} /$ capita/day, the winter and summer wastewater discharge are $750 \mathrm{~m}^{3} /$ day, $900 \mathrm{~m}^{3} /$ day respectively. For (BOD) concentration of 50 $\mathrm{g} /$ capita/day of the untreated influent $(330 \mathrm{mg} / \mathrm{L})$ and after dilution by the agriculture drainage water of Tal ELHabow drain (average discharge of $20000 \mathrm{~m}^{3} /$ day) reduced to an average of $62 \mathrm{mg} / \mathrm{L}$ (Table 2). Therefore, the proposed design flow in this study is $6000 \mathrm{~m}^{3} /$ day that will be diverted from Tal EL-Habow drain into the (SFCWL) system. The proposed (SFCWL) system is followed by a storage pond to the store treated wastewater (Fig. 6). 


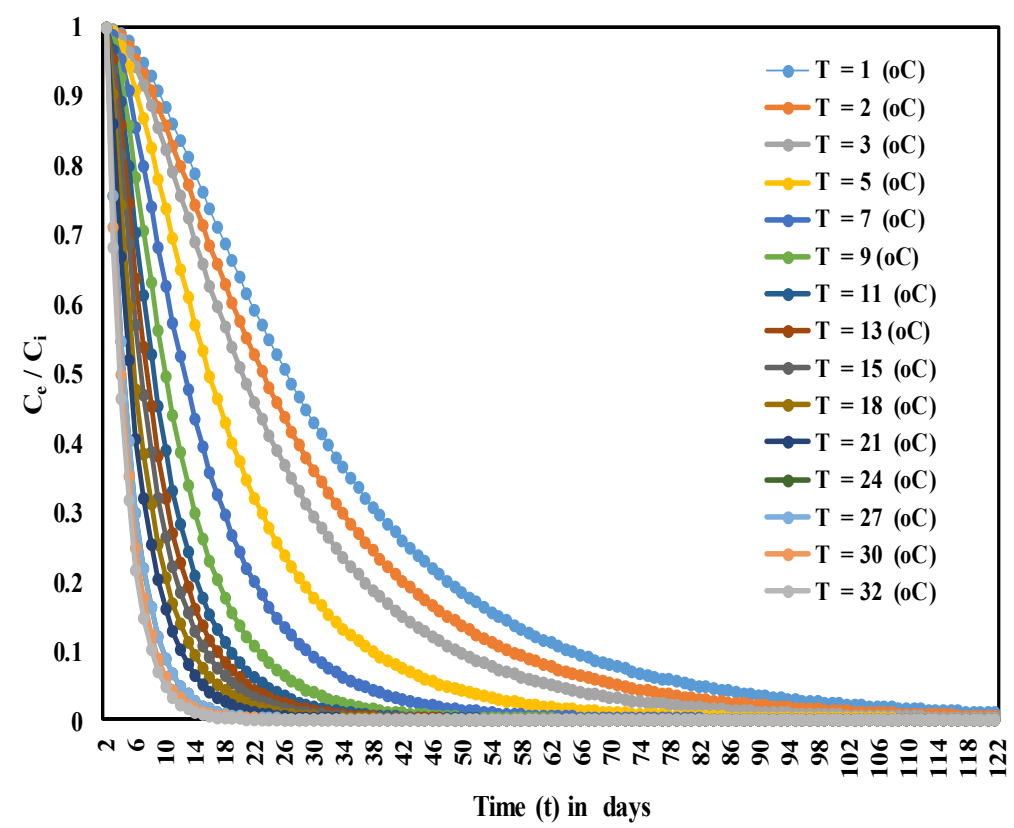

Fig. 4: Nomo-graph for nitrogen removal efficiency for (SFCWL) [11].

Table 3. Existing and predicted area of the SFCWL systems based on Kadlec and Knight (1996) database [12].

\begin{tabular}{|c|c|c|c|c|c|c|c|c|c|}
\hline \multirow[t]{2}{*}{ System Name } & \multirow{2}{*}{$\begin{array}{c}\text { (Temp.) } \\
\left({ }^{\circ} \mathrm{C}\right)\end{array}$} & \multirow{2}{*}{$\begin{array}{c}(\mathrm{Q}) \\
\left(\mathrm{m}^{3} / \mathrm{d}\right)\end{array}$} & \multicolumn{2}{|c|}{ Concentrations } & \multirow{2}{*}{$\begin{array}{l}\text { Wetland } \\
\text { surface } \\
\text { area } \\
\text { existing } \\
\text { (ha) }\end{array}$} & \multicolumn{2}{|c|}{$\begin{array}{c}\text { Wetland } \\
\text { surface area } \\
\text { Predicted (Ap) } \\
\text { (Hectare) }\end{array}$} & \multicolumn{2}{|c|}{$\begin{array}{c}\text { Matching } \\
\text { Ratio } \\
(\%)\end{array}$} \\
\hline & & & $\begin{array}{c}\text { Influent }\left(C_{i}\right) \\
(\mathrm{mg} / \mathrm{L})\end{array}$ & $\begin{array}{c}\text { Effluent }\left(C_{e}\right) \\
(\mathrm{mg} / \mathrm{L})\end{array}$ & & $\begin{array}{c}\text { (L: B) } \\
(2: 1)\end{array}$ & $\begin{array}{l}\text { (L: B) } \\
(5: 1)\end{array}$ & $\begin{array}{c}\text { (L: B) } \\
(2: 1)\end{array}$ & $\begin{array}{c}\text { (L: B) } \\
(5: 1)\end{array}$ \\
\hline $\begin{array}{l}\text { W. Jackson } \\
\text { County, USA }\end{array}$ & 5.0 & 6268 & $(B O D)=25.93$ & $(\mathrm{BOD})=7.40$ & 22.7 & 12.8 & 10.2 & -77.3 & -51 \\
\hline $\begin{array}{l}\text { Bear Bay, SC, } \\
\text { USA }\end{array}$ & 6.0 & 877 & $\begin{array}{c}(\mathrm{BOD})=13.50 \\
(\mathrm{TN})=17.58 \\
(\mathrm{TP})=3.88\end{array}$ & $\begin{array}{c}(\mathrm{BOD})=1.90 \\
(\mathrm{TN})=2.35 \\
(\mathrm{TP})=0.40\end{array}$ & 28.3 & 18.2 & 14.5 & -35.7 & -48.8 \\
\hline $\begin{array}{l}\text { Fort Deposit, } \\
\text { AL, USA }\end{array}$ & 9.0 & 674 & $(\mathrm{BOD})=32.90$ & $(\mathrm{BOD})=6.90$ & 6.0 & 2.4 & 1.9 & -60.0 & -68.3 \\
\hline $\begin{array}{l}\text { Mt View CA, } \\
\text { USA }\end{array}$ & 5.0 & 2821 & $(B O D)=33.40$ & $(\mathrm{BOD})=23.10$ & 4.3 & 2.1 & 1.6 & -51.2 & -62.8 \\
\hline $\begin{array}{l}\text { Boggy Gut, } \\
\text { SC, USA }\end{array}$ & 6.0 & 5827 & $\begin{array}{c}(\mathrm{BOD})=6.30 \\
(\mathrm{TN})=11.22 \\
(\mathrm{TP})=4.26\end{array}$ & $\begin{array}{l}(\mathrm{BOD})=3.0 \\
(\mathrm{TN})=3.53 \\
(\mathrm{TP})=3.35\end{array}$ & 20.2 & 48.0 & 38.2 & 137.6 & 89.1 \\
\hline
\end{tabular}

(Temp.), Temperature; (Q), discharge; and (L: B), length to width ratio.

The discharge is divided into 8 surface flow constructed wetland each one has a discharge of $750 \mathrm{~m}^{3} /$ day. The performance criteria consider (BOD), (TSS), (TN), (TP) and (FC), the input data of the model is summarized in Table 4. Design winter and summer air temperature are 15 ${ }^{\circ} \mathrm{C}$ and $27^{\circ} \mathrm{C}$, respectively. Influent (BOD) and (FC) are $120 \mathrm{mg} / \mathrm{L}$ and $100000 \mathrm{CFU} / 100 \mathrm{~mL}$ respectively. Influent (TN) and (TP) are $20 \mathrm{mg} / \mathrm{Land} 5 \mathrm{mg} / \mathrm{L}$ respectively, and influent $(\mathrm{TSS})=155 \mathrm{mg} / \mathrm{L}$. In addition, $\mathrm{L} / \mathrm{B}=3, \mathrm{x}=10^{7}$, porosity $(\mathrm{n})=0.65, \alpha_{\text {winter }}=0.1, \alpha_{\text {summer }}=0.09(\alpha$ is the fraction of the depth serving as head differential depending on (TSS) and porosity), effluent (BOD) $=16$ $\mathrm{mg} / \mathrm{L}$, and effluent $(\mathrm{FC})=500 \mathrm{CFU} / 100 \mathrm{~mL}$. The model output results (Table 5) shows that winter conditions controls (BOD) area removal winter computed from
Equations $(2,4)$ indicates (BOD) area removal of 18736.2 $\mathrm{m}^{2}$ with a $(\mathrm{RT})=3.54$ days, and the value of Coliforms area removal in summer computed from Equations $(3,4)$ is $13245.8 \mathrm{~m}^{2}$.

Therefore, width (B) is $79 \mathrm{~m}$, and length (L) is $237 \mathrm{~m}$. Fig. 7 shows the design plan of the proposed (SFCWL) system, it consists of full vegetated zone of length $100 \mathrm{~m}$ followed by open water surface zone of length $37 \mathrm{~m}$ followed by full vegetated zone (reed plants) of length $100 \mathrm{~m}$. According to the USEPA 1999 [3] considerable open water area between fully vegetated zones increases effluent quality and disinfection of the effluent through the aerobic transformations and removal opportunities. 


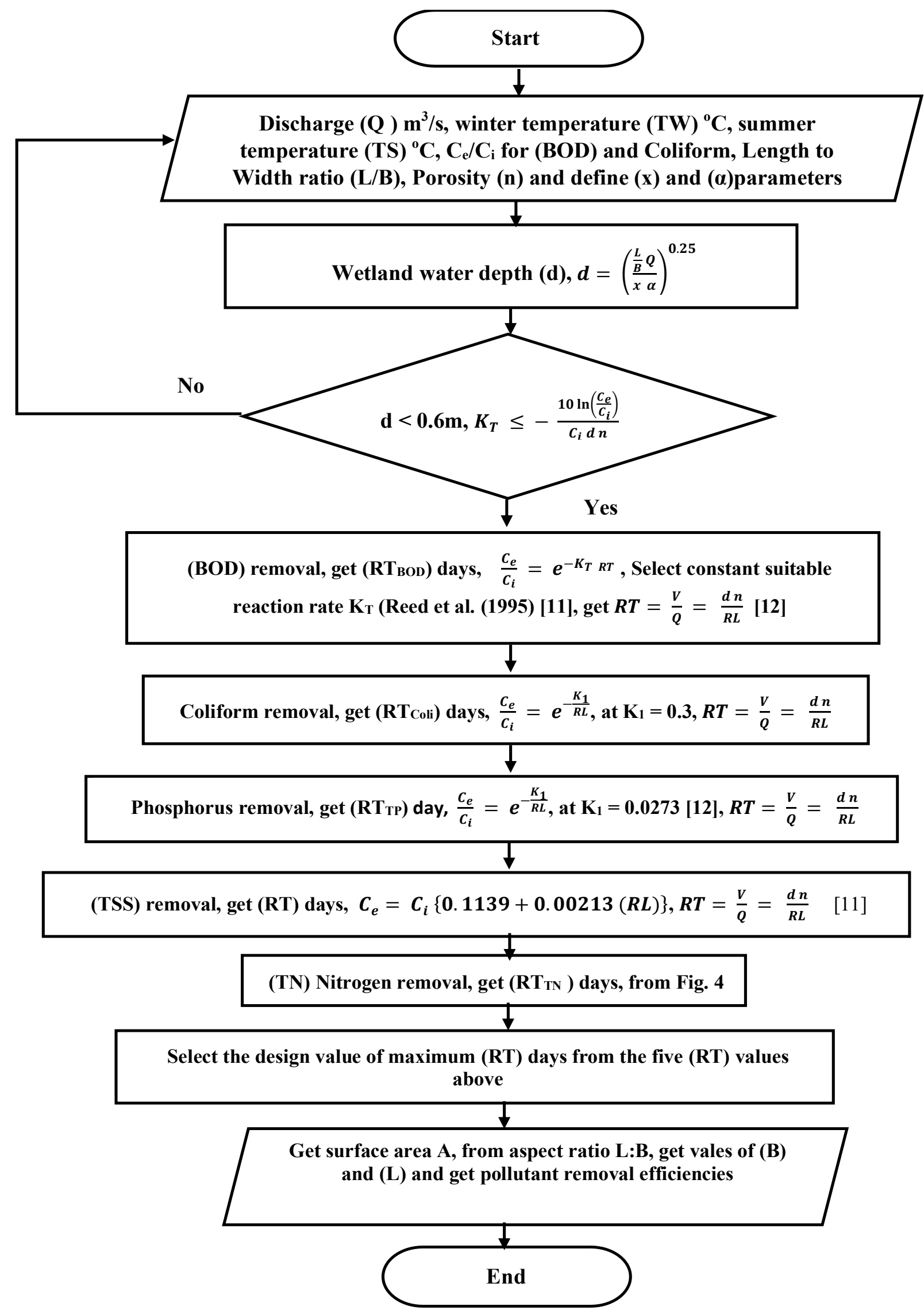

Fig. 5: Flow chart diagram for the methodology adopted 
Table 4. Model input data

\begin{tabular}{|c|c|}
\hline Summer population $=6000$ Capita & $\begin{array}{l}\text { Design influent fecal coliforms (FC) } \\
=(100000 \mathrm{CFU} / 100 \mathrm{~mL})\end{array}$ \\
\hline Winter population $=5000$ Capita & Influent total Nitrogen $(\mathrm{TN})=20 \mathrm{mg} / \mathrm{L}$ \\
\hline Unit wastewater flow $=0.15 \mathrm{~m}^{3} /$ capita $/$ day & Influent total Phosphorus $(\mathrm{TP})=5 \mathrm{mg} / \mathrm{L}$ \\
\hline Wastewater winter discharge $=750 \mathrm{~m}^{3} /$ day & Influent $(\mathrm{TSS})=155 \mathrm{mg} / \mathrm{L}$ \\
\hline Wastewater summer discharge $=900 \mathrm{~m}^{3} /$ day & $\mathrm{x}=10^{7}$ \\
\hline $\begin{array}{c}\text { Design discharge }=750 \mathrm{~m}^{3} / \text { day diverted from Tal } \mathrm{Al}- \\
\text { Habwah branch-drain. }\end{array}$ & $\mathrm{L} / \mathrm{B}=3$ \\
\hline Design winter air temperature $=15^{\circ} \mathrm{C}$ & Porosity $(\mathrm{n})=0.65$ \\
\hline Design summer air temperature $=27^{\circ} \mathrm{C}$ & $\begin{aligned} \alpha_{\text {winter }} & =0.1 \\
\alpha_{\text {summer }} & =0.09\end{aligned}$ \\
\hline Primary influent $(\mathrm{BOD})=330 \mathrm{mg} / \mathrm{L}$ & Effluent $(\mathrm{BOD})=20 \mathrm{mg} / \mathrm{L}$ \\
\hline $\begin{array}{l}\text { Design influent }(\mathrm{BOD})=120 \mathrm{mg} / \mathrm{L} \text { (after dilution in } \\
\text { drainage water of Tal } \mathrm{Al}-\mathrm{Habwah} \text { branch-drain) }\end{array}$ & Effluent fecal coliforms $(\mathrm{FC})=500 / 100 \mathrm{~mL}$ \\
\hline
\end{tabular}

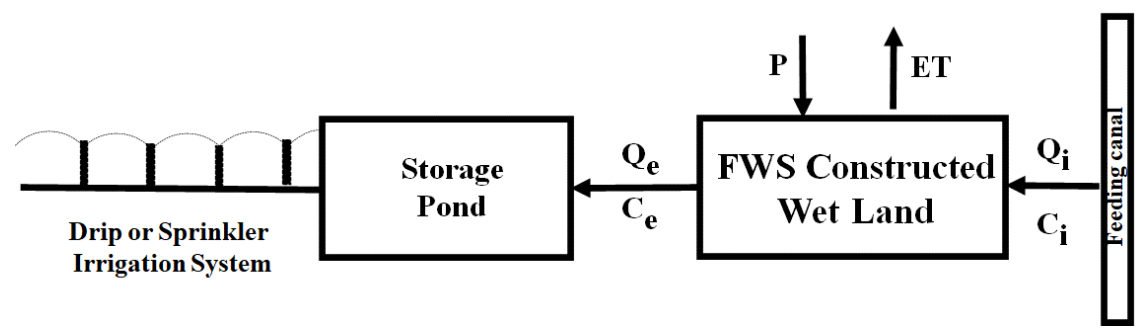

Fig. 6: Diagram of the proposed (SFCWL) treatment system

Table 5. Model output

\begin{tabular}{|c|c|}
\hline \multicolumn{2}{|c|}{ Winter and summer water depth $(\mathrm{d})=0.22 \mathrm{~m}$} \\
\hline (BOD) residence time $(\mathrm{RT})=3.54$ days & Wetland $(\mathrm{BOD})$ area $=18736.2 \mathrm{~m}^{2}$ \\
\hline Hydraulic load $(\mathrm{RL})=0.0566 \mathrm{~m} /$ day & Wetland Coliforms area $=13245.8 \mathrm{~m}^{2}$ \\
\hline \multicolumn{2}{|c|}{ Winter condition control the design } \\
\hline \multicolumn{2}{|c|}{$(\mathrm{RT})=3.54$ days } \\
\hline \multicolumn{2}{|c|}{$(A)=18736.2 \mathrm{~m}^{2}$} \\
\hline \multicolumn{2}{|c|}{$\mathrm{L} / \mathrm{B}=3, \mathrm{~B}=79 \mathrm{~m}, \mathrm{~L}=237 \mathrm{~m}$} \\
\hline Effluent $(\mathrm{TP})$ winter $=2.8 \mathrm{mg} / \mathrm{L}$ & Effluent $(\mathrm{TP})$ summer $=2.5 \mathrm{mg} / \mathrm{L}$ \\
\hline Effluent $(\mathrm{TN})$ winter $=6.83 \mathrm{mg} / \mathrm{L}$ & Effluent $(\mathrm{TN})$ summer $=6.8 \mathrm{mg} / \mathrm{L}$ \\
\hline \multicolumn{2}{|c|}{ Effluent $(\mathrm{TSS})=17.7 \mathrm{mg} / \mathrm{L}$} \\
\hline (BOD) removal efficiency $=83.33 \%$ & $(\mathrm{FC})$ removal efficiency $=99.5 \%$ \\
\hline$(\mathrm{TP})$ removal efficiency $=50 \%$ & $(\mathrm{TN})$ removal efficiency $=66 \%$ \\
\hline (TSS) remov & $y=88.6 \%$ \\
\hline
\end{tabular}

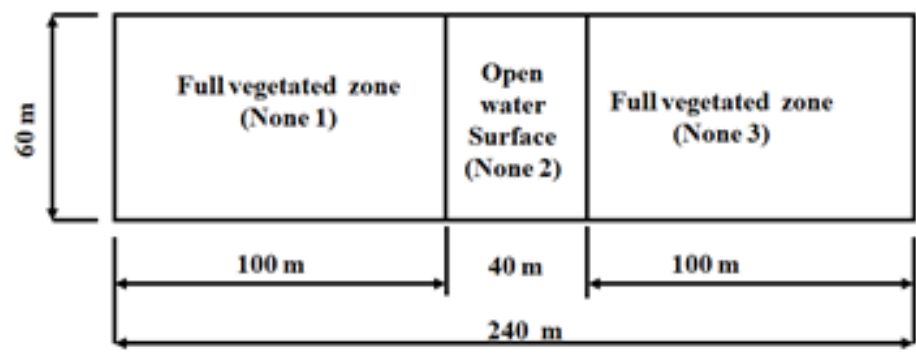

Fig. 7: Design plan of the proposed constructed wetland 


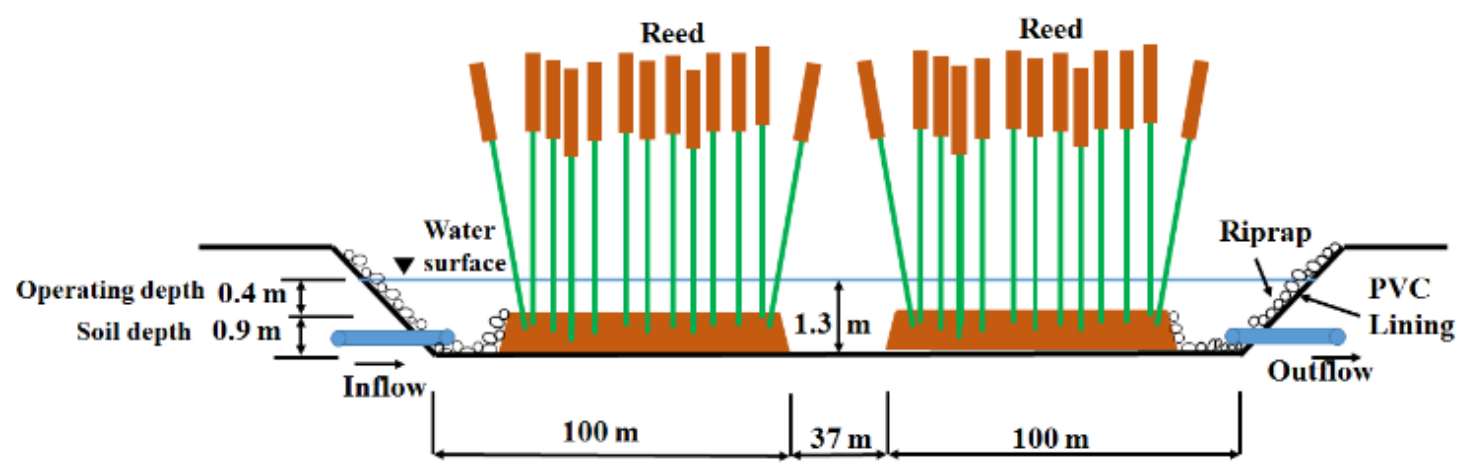

Fig. 8: Cross-section elevation of the proposed constructed wetland.

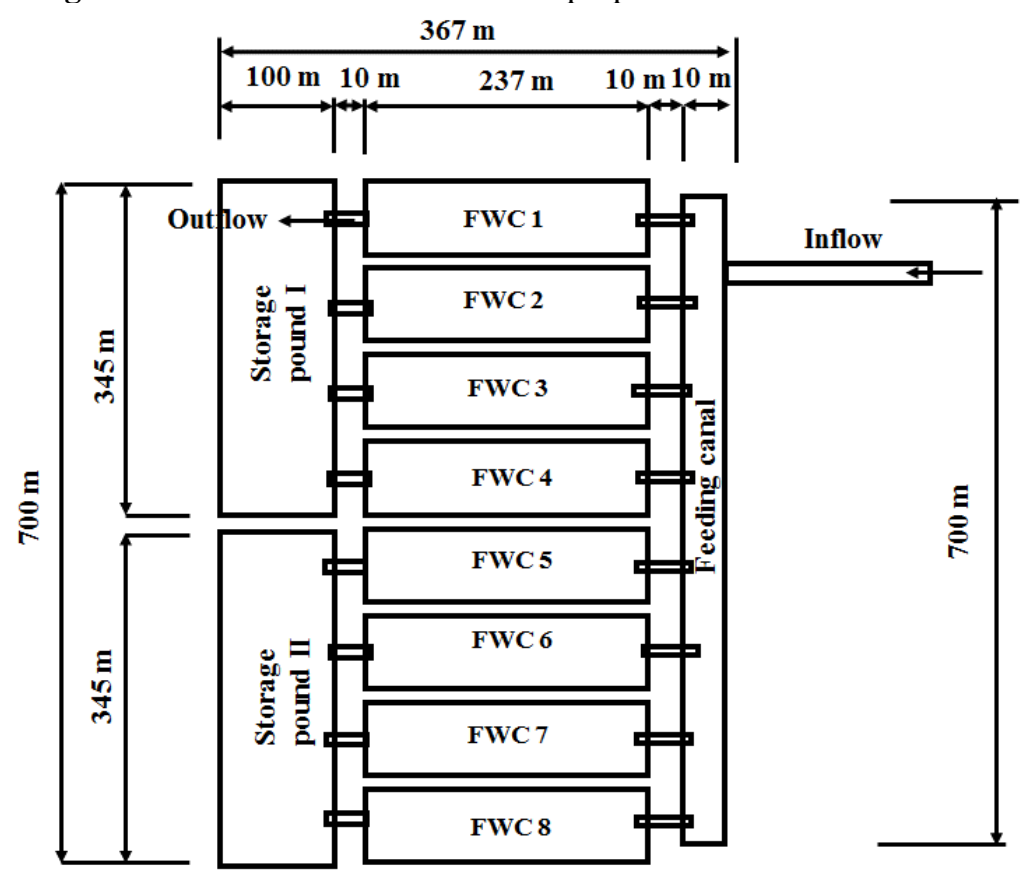

Fig. 9: Proposed (SFCWL) system plan.

Table 6. Estimated water balance for (SFCWL) (18 ha) in Tina plain region, North Sinai Egypt.

\begin{tabular}{|c|c|c|c|c|}
\hline Month & $\begin{array}{c}\text { Proposed Average } \\
\text { Inflow } \\
\left(\mathrm{m}^{3} / \text { day }\right)\end{array}$ & $\begin{array}{c}\text { Net } \\
\text { Precipitation } \\
\text { (mm/month) }\end{array}$ & $\begin{array}{c}\text { Water Loss } \\
\left(\mathbf{m}^{3} / \text { day }\right)\end{array}$ & $\begin{array}{l}\text { Outflow } \\
\left(\mathrm{m}^{3} / \text { day) }\right.\end{array}$ \\
\hline January & 6000 & -72.5 & -435 & 5565.00 \\
\hline February & 6000 & -98.4 & -590.4 & 5409.60 \\
\hline March & 6000 & -132.5 & -795 & 5205.00 \\
\hline April & 6000 & -185.8 & -1114.8 & 4885.20 \\
\hline May & 6000 & -210.7 & -1264.2 & 4735.80 \\
\hline June & 6000 & -240.9 & -1445.4 & 4554.60 \\
\hline July & 6000 & -232.5 & -1395 & 4605.00 \\
\hline August & 6000 & -211.2 & -1267.2 & 4732.80 \\
\hline September & 6000 & -174.6 & -1047.6 & 4952.40 \\
\hline October & 6000 & -131.8 & -790.8 & 5209.20 \\
\hline November & 6000 & -78.6 & -471.6 & 5528.40 \\
\hline December & 6000 & -64.3 & -385.8 & 5614.20 \\
\hline Total & 72000 & -1833.8 & -11002.8 & 60997.20 \\
\hline Average & 6000 & -152.817 & -916.9 & 5083.1 \\
\hline
\end{tabular}

-The negatives value means evapotranspiration is higher the precipitation 
Fig. 8 shows the cross-section elevation of the proposed (SFCWL) system for $0.4 \mathrm{~m}$ operating depth and $0.9 \mathrm{~m}$ soil depth. Poly Venial Chloride (PVC) sheets to prevent seepage losses line the wetland. For total discharge 6000 $\mathrm{m}^{3} /$ day, the required (SFCWL) area is about 16.6 hectares. The computed overall pollutant removal efficiencies for (BOD) and (FC) are $87 \%$ and $99.7 \%$ respectively. The (TN) removal efficiency is $66 \%$, and (TP) removal efficiency is $50 \%$. (TSS) removal efficiency is $88.6 \%$. Storage pond is necessary to adjust application rates. Therefore, the tank is designed to store a minimum of 30 days of design flow $\left(6000 \times 30 \mathrm{~m}^{3}\right)$. It is proposed to have two storage ponds each one of $5.2 \mathrm{~m}$ depth, $100 \mathrm{~m}$ width, and 345 length (Fig. 9). The proposed total area of the free water surface constructed wetland system and the storage tank is 25.7 hectares $(700 \mathrm{~m} \times 367 \mathrm{~m})$ including service roads to treat a discharge of $6000 \mathrm{~m}^{3} /$ day (Fig. 9).

\subsection{Wetland Hydrology}

The climatic data of the study area indicate a semi-arid region therefore the catchment runoff and snowmelt were neglected. In addition, a lining or geo-textiles is consider for the wetland bed and side slopes for no water infiltration. According to Equation (1) (Kadlec and Wallace [17], climatic data in Table 1 and the design discharge of $6000 \mathrm{~m}^{3} /$ day for computed wetland area of 18 hectares, the average net precipitation (net amount of received water from the atmosphere) is an evapotranspiration of $917 \mathrm{~m}^{3} /$ day. Table 6 summarizes Wetland Hydrology computation. In this study, the design discharge is constant therefore, the loss by evaporation can be substituted from the flow diverted from Tal ELHabow drain $\left(20000 \mathrm{~m}^{3} /\right.$ day) to the proposed (SFCWL).

\section{CONCLUSIONS AND FUTURE DIRECTIONS}

The wetland treatment system is a promising low-cost wastewater treatment alternative that can protect watercourses and lakes from pollution. A model is developed based on simple equations to design free water surface constructed wetland system, taking into consideration the removal requirement biological oxygen demand (BOD), fecal coliform (FC), total suspended solids (TSS), Total Nitrogen (TN) and total Phosphorus (TP) based on first-order kinetics and the assumptions of plug flow requirements $\left(\mathrm{k}-\mathrm{C}^{*}\right.$ model). The model was utilized to assess the feasibility of constructing a (SFCWL) system to reclaim degraded agricultural drainage water in East South EL-Kantara Region (Tal AlHabwah branch-drain) North Sinai, Egypt.

The results of the agriculture drainage wastewater quality for Tal Al-Habwah branch-drain show an average concentrations of $7.9,62 \mathrm{mg} / \mathrm{L}, 150 \mathrm{mg} / \mathrm{L}, 28 \mathrm{mg} / \mathrm{L}, 1.8$ $\mathrm{mg} / \mathrm{L}, 1.1 \mathrm{mg} / \mathrm{L}$ and $500 \mathrm{FCU} / 100 \mathrm{~mL}$ for the $(\mathrm{pH})$, (BOD), (TSS), $\left(\mathrm{NO}_{3}\right),(\mathrm{Fe}),(\mathrm{Zn})$ and $(\mathrm{FC})$ respectively. Therefore, the drainage water needs treatment prior to discharge into Suez Canal or to be reused in other purposes. The proposed (SFCWL) treatment system comprises of a secondary treatment unit consists of a densely vegetated (reed) surface wetland cells and a storage pond. The constant influent discharge of 6000 $\mathrm{m}^{3}$ /day at summer air temperature of $27{ }^{\circ} \mathrm{C}$, winter air temperature $15^{\circ} \mathrm{C},(B O D)$ concentration of $120 \mathrm{mg} / \mathrm{L}$, (FC) $100000 \mathrm{CFU} / 100 \mathrm{~mL}$, (TSS) $155 \mathrm{mg} / \mathrm{l}$, (TN) and (TP) concentrations of 20 and $5 \mathrm{mg} / \mathrm{L}$, respectively. Effluent (BOD) and (FC) are $20 \mathrm{mg} / \mathrm{L}$ and $500 \mathrm{CFU} / 100$ $\mathrm{mL}$ respectively. The results show total treatment system area of 25.7 hectares including storage tank and service roads (700 m long and $370 \mathrm{~m}$ width), expected overall (BOD) $87 \%$, (FC) removal $99.7 \%$, and (TSS) $88.6 \%$ after a treatment detention time of 3.54 days. The system has a capacity to irrigate about 140 hectares every day of the popular cultivations.

The contributions of this study can be summarized as follows: first, the proposed wastewater treatment system will assist in East South EL-Kantara Region by treating its daily domestic wastewater through an environmentally friendly manner. Second, the study tackled the pressing water shortage problems and provided a low-cost strategy that can bring multiple benefits to the water resource management. Third, environmental health and public health conditions are expected to be improved after the enhancement of wastewater quality. Forth, this study serves as an exemplary case for other communities that are facing similar water shortage problems or lack of financial resources to construct costly traditional wastewater treatment plants. Community and stakeholder cooperation are the key issue in such system success. Sustainable operation and maintenance by local governorate will reduce treatment expenses.

\section{Acknowledgement}

I am thankful for the special logistical and technical support delivered by the Sector of Water Resources, Irrigation, and Infrastructures at the North of Sinai and Environment, and Channel Maintenance Research Institute, National Water Research Center (CMRI), Ministry of Water Resources and Irrigation (MWRI), Egypt.

\section{References}

[1] Changwoo A. and Stephanie SD., Wetlands as an essential infrastructural element for urban development in the era of climate change. Journal of Sustainability, 11, 1920, 2019

[2] WHO (World Health Organization), health guidelines for the use of wastewater in agriculture and aquaculture, technical report series 778, WHO, Geneva, 1989.

[3] USEPA, U.S. Environmental Protection Agency, U.S. EPA manual: Constructed wetlands treatment of municipal wastewaters (EPA/625/R-99/010). Cincinnati, OH: National Risk Management Research Laboratory, Office of Research and Development, 1999. 
[4] Eric, R.R., Andrew, C.V., Jeff, D.W., Aleksandra, D., Youbin, Z., Ali, M., and Robert J.G., Constructed wetlands for agricultural wastewater treatment in Northeastern North America: A Review. Water, 8, 173, 2016.

[5] Ahmed, G., Latifa B., Fabio M., and Martin R., Constructed wetland as a low cost and sustainable solution for wastewater treatment adapted to rural settlements: the Chorfech wastewater treatment pilot plant. Water Science \& Technology 63.12, 2011.

[6] Xinxi, F., Xiaofu, W., Sangyang, Z., Yonghua, C., Mingli C., and Runhua C., A constructed wetland system for rural household sewage treatment in subtropical regions. Water 10, 716, 2018.

[7] DeHaan, R., MacLeod, J., Murray, B., Raymond, B., Duffy, T., MacFarlane, A., Coffin, R. Constructed Wetland Project, PEIDAF: Charlottetown, PE, Canada, 2003.

[8] Carreau, R., VanAcker, S., VanderZaag, A.C., Madani, A., Drizo, A., Jamieson, R., and Gordon, R., Evaluation of a surface flow constructed wetland treating abattoir wastewater, Appl. Eng. Agric. 28, 757-766, 2012.

[9] Kamal Güneş, Beyhan Oktar, Selma Ayaz, Bilal Tunçsiper, et. al., Large scale constructed wetland implementation projects in Turkey in Salt Lake Special Environmental Protection Area, Desalination and water treatment 51(22):1-10, 2013.

[10] Maiga, Y., von Sperling, M. and Mihelcic, J.R., Constructed Wetlands. In: J.B. Rose and B. Jiménez-Cisneros, (eds) Global Water Pathogen Project, 2017.

[11] Reed, S. C., Ronalad W. C., Middlebrooks, E. J., Natural systems for waste management and treatment, 2nd ed. McGraw-Hill, Inc, New York, U.S.A, 1995.

[12]Kadlec, H. R. and Knight, R. L., Treatment wetlands, Lewis Publishers, Boca Raton, U.S.A, 1996.

[13] Economopoulou, M. A. and Tsihrintzis, V. A., Design methodology of free water surface, water resources management 18: 541-565, 2004.

[14] Toshio S., Manzoor Q., Sadahiro Y., Tsuneyoshi E., and Ahmad Z., Impact of the hydraulic loading rate on pollutants removal in tropical horizontal subsurface flow constructed wetlands, Ecological Engineering 61,154- 160, 2013.

[15] Kadlec, R., Large constructed wetlands for phosphorus control: A review. Water, 8, 243, 2016.

[16] Knight, R.L., Payne, V.W., Borer, R.E., Clarke, R.A., and Pries, J.H., Constructed wetlands for livestock wastewater management. Ecol. Eng. 15, 41-55, 2000.

[17] Kadlec, R.H., and Wallace, S.D., Treatment wetlands, 2nd ed.; CRC Press: Boca Raton, FL, USA, p. 1046, 2008.
[18] Rashed, A., El-Refaie, G., El-Hawary, A. Assessing the effectiveness of surface wetland treatment system on drainage water quality. In: NAWQAM Project, Final Conference, Sharm El-Sheikh, Egypt, 2007.

[19] El-Hawary, A., and Shaban, M., 2018. Improving drainage water quality: Constructed wetlands-performance assessment using multivariate and cost analysis. Water Science. Water Science 32 301-317, 2018.

[20] Abou EL-Kheir, W., Ismail, G., EL-Nour, F., Tawfik, T., and Hammad, D., Assessment of the efficiency of duckweed (Lemna gibba) in wastewater treatment. Int. J. Agric. Biol., 1560, 2007.

[21] FAO (Food and Agriculture Organization), Land and Water Division, CROPWAT Software, Available online: http://www.fao.org/landwater/databases-andsoftware/cropwat/en/ (accessed on 20 August 2019).

[22] CMRI-Channel Maintenance Research Institute, National Water Research Center, Ministry of Water Resources and Irrigation (MRWI), Assessing of the status of maintenance of irrigation and drainage networks in the North Sinai Project, North Sinai, technical report submitted to the Sector of Water Resources, Irrigation, and Infrastructures at the North of Sinai (SIWRI), MWRI, 2010. (In Arabic).

[23] Gabr, M., Magnitude and characteristics of sand dunes encroachment towards El-Sheikh Gaber Canal, North Sinai, Egypt. Twenty-first International Water Technology Conference, IWTC 21 Ismailia, 28-30 June 2018.

[24]APHA, AWWA, WEF, Standard methods for examination of water and wastewater. $22^{\text {nd }}$ ed. 1360 pp. Washington: American Public Health Association, 2012.

[25] DRI-Drainage Research Institute, National Water Research Center, Ministry of Water Resources and Irrigation (MRWI), Assessing of water quality of the irrigation and drainage networks in the North Sinai Project, North Sinai, technical report submitted to the Sector of Water Resources, Irrigation, and Infrastructures at the North of Sinai (SIWRI), MWRI, 2010. (In Arabic).

[26] Egypt Decree no. 92 for the year 2013 concerning the Protection of the Nile River and its Waterways from Pollution. Decree of Minister of Water Resources and Irrigation, Executive Regulation of Law 48/1982, 2013 (in Arabic).

[27] Reed, S. C. and Brown, D., Constructed wetland design-the second generation, natural system Digest, Water Environment Federation Digest Series, 1993.

[28] Gabr, M., Evaluation of irrigation water, drainage water, soil salinity, and groundwater for sustainable cultivation. Irrigat Drainage Sys Eng 7: 224,2018 
[29] Gabr, M., Drainage management problems evaluation: case Study Baloza and EL-Farama Drains, North Sinai, Egypt. Journal of Water Resource and Protection, 11, 675-689, 2019.

\section{منهجية تصميم نظام الأراضي الرطبة السطحية المشيدة، دراسة

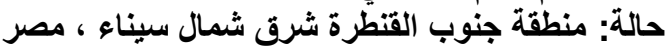

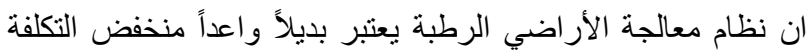

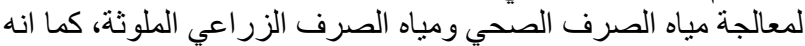

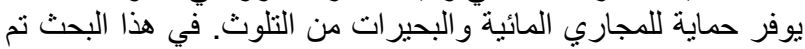

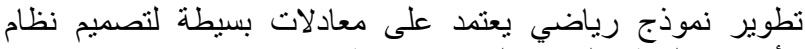

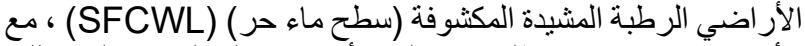

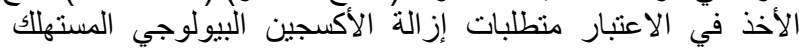

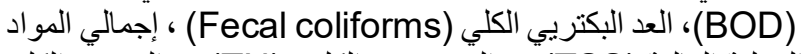

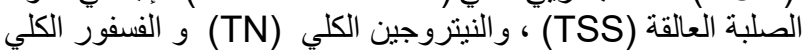
و على افتراضات منطلبات تدفق المكونات و هيدروليكا النظام (TP)

طبقا لنموذج (Kadlec).

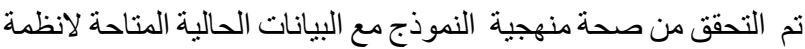

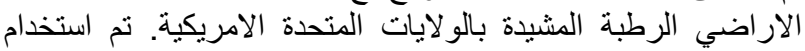

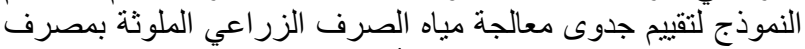

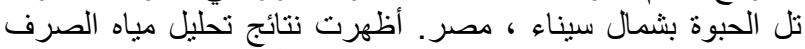

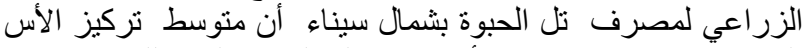

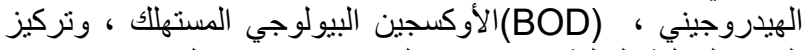

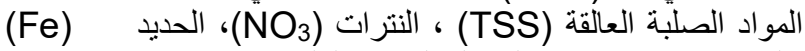

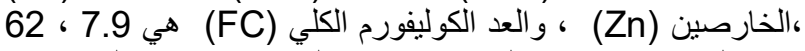

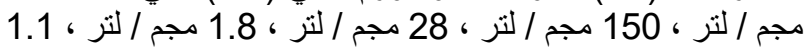

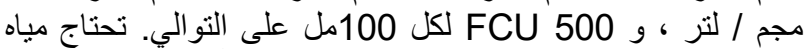
الصرف إلى المعالجة قبل تصريفها في قناة السويس أو لإعادة استخدامها

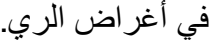

تم تطبيق النموذج لتصميم نظام معالجة الأراضي الرطبة المقترح

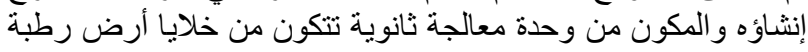

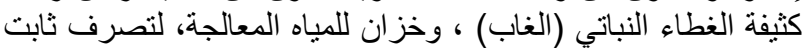

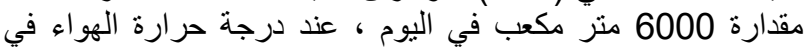

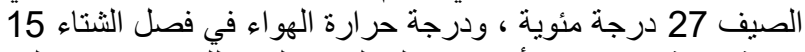

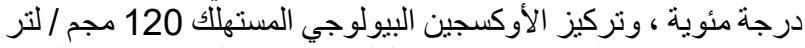

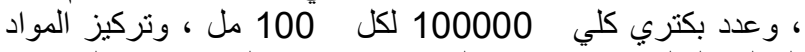

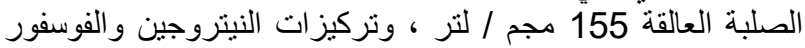

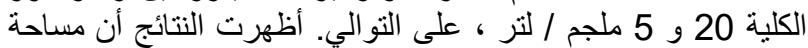

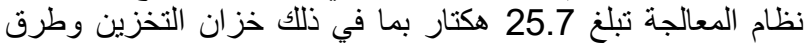

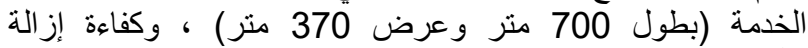

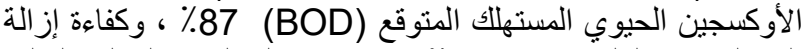

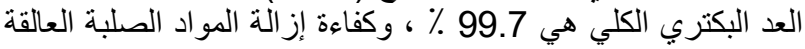

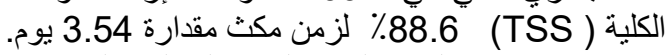

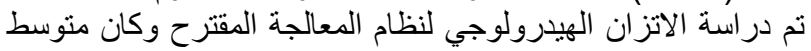

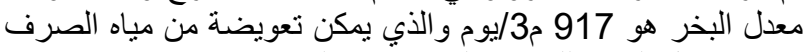

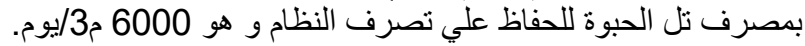

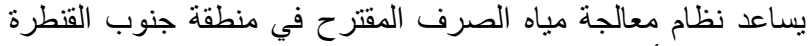

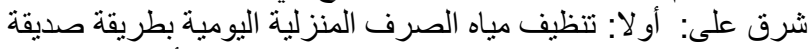

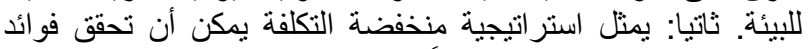

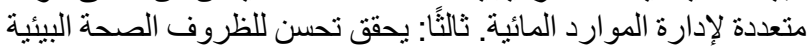

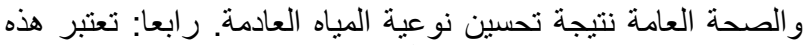

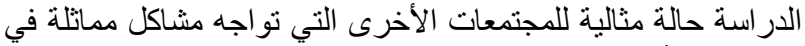

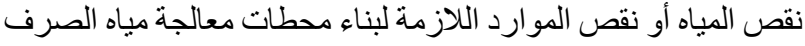

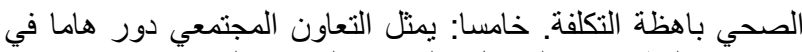

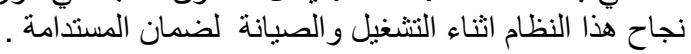

